\title{
Statyba
}

\section{ON THE ANALYSIS OF GEOMETRICALLY NONLINEAR STRUCTURES}

\section{R. Karkauskas}

To cite this article: R. Karkauskas (1997) ON THE ANALYSIS OF GEOMETRICALLY NONLINEAR STRUCTURES, Statyba, 3:12, 38-43, DOI: 10.1080/13921525.1997.10531365

To link to this article: https://doi.org/10.1080/13921525.1997.10531365

册 Published online: 26 Jul 2012.

Submit your article to this journal

山 Article views: 50 


\section{ON THE ANALYSIS OF GEOMETRICALLY NONLINEAR STRUCTURES}

\section{R.Karkauskas}

\section{Introduction}

Consider a stress and strain field (SSF) evaluation of elastic pin-jointed and framed structures for the case of large displacements and small strains. This case is the most urgent in practice. Due to small strains of bar they are neglected when formulating the equilibrium equations. Thus, the bar prior and after deformation remains straight.

Most of the practical formulations [1-4] for the geometrical nonlinear problems are presented in the form of incremental displacement based on equilibrium equations by using a virtual displacement method. The variational functional formulations [5] also contains the same technique implicitly and are of major theoretical but minor practical interest.

A new approach of equilibrium finite element method [6,7] to the analysis of geometrically nonlinear structures is suggested in this paper. It means that the stresses are identified as the basic variables, while the equilibrium equations coefficients may be obtained, for example, from equilibrium equations of junctions and bars of the deformed discrete model of the structure.

There exist no unique explicit rules and recommendations for the formulation and solution of any geometrical nonlinear problem. Interpretation and adjustment of particular factors and terms are necessary for reliable and rational nonlinear models.

\section{Mathematical model of the problem}

By its nature every pin-jointed and framed structure is a discrete system. When analysing it, each bar between the junctions and points of application of the concentrated external forces can be regarded as a separate element with its intrinsic set of computable quantities in the design cross-sections. The discrete model of the structure is obtained by dividing it into $k$ cross-sections, the total number of them being $n_{k}$.

Thus, suppose that the SSF of the discrete model of the structure consists of two pairs of dual variables.
The first one consists of the force vector $S$ and the generalised strain vector $q$ :

$$
\begin{aligned}
& \mathbf{S} \equiv\left(\mathbf{S}_{k}\right)^{T}=\left(M_{k}, N_{k}\right)^{T}=\left(S_{j}\right)^{T}, \\
& \mathbf{q} \equiv\left(\mathbf{q}_{k}\right)^{T}=\left(\varphi_{k}, \Delta l_{k}\right)^{T}=\left(q_{j}\right)^{T}, \\
& k=1,2, \ldots, n_{k}, j=1,2, \ldots, n \leq 2 n_{k} .
\end{aligned}
$$

Another pair consists of the loading and displacements. It is well known that the dimension of the load vector $\mathbf{F}$ and the generalised displacement vector $\mathbf{u}$ corresponds to the degrees of freedom $m$. Then the vectors

$$
\mathbf{F}=\left(F_{i}\right)^{T}, \mathbf{u}=\left(u_{i}\right)^{T}, i=1,2, \ldots, m .
$$

In general case, the equilibrium equations of the discrete model of the structure for deformed state consists of equilibrium equations of junctions and bars. They read:

$$
[A(u)] \mathbf{S}=\mathbf{F} .
$$

Here $[A(u)]-(n \times m)$ is dimension matrix of equilibrium equations, linear related to displacements of joints and bars of discrete model. Fig 1 shows any deformed state junction in global coordinate system, related to discrete system in undeformed state.

The equilibrium equations, formulated for the $\eta$-th junction, read:

$$
\sum M_{\eta}=0 ; \quad M_{d}+M_{k}+M_{a}+M_{v}=M_{\eta},
$$

$$
\begin{gathered}
\sum X_{\eta}=0 ; \quad \begin{array}{r}
Q_{d} \sin \alpha_{d}-Q_{k} \sin \alpha_{k}+Q_{a} \cos \alpha_{a}- \\
-Q_{v} \cos \alpha_{v}-N_{d} \cos \alpha_{d}+N_{k} \cos \alpha_{k} \\
-N_{a} \sin \alpha_{a}+N_{v} \sin \alpha_{v}=F_{\eta x}
\end{array} \\
\sum Y_{\eta}=0 ; \quad-Q_{d} \cos \alpha_{d}+Q_{k} \cos \alpha_{k}-Q_{a} \sin \alpha_{a}+ \\
+Q_{v} \sin \alpha_{v}-N_{d} \sin \alpha_{d}+N_{k} \sin \alpha_{k} \\
-N_{a} \cos \alpha_{a}+N_{v} \cos \alpha_{v}=F_{\eta y}
\end{gathered}
$$




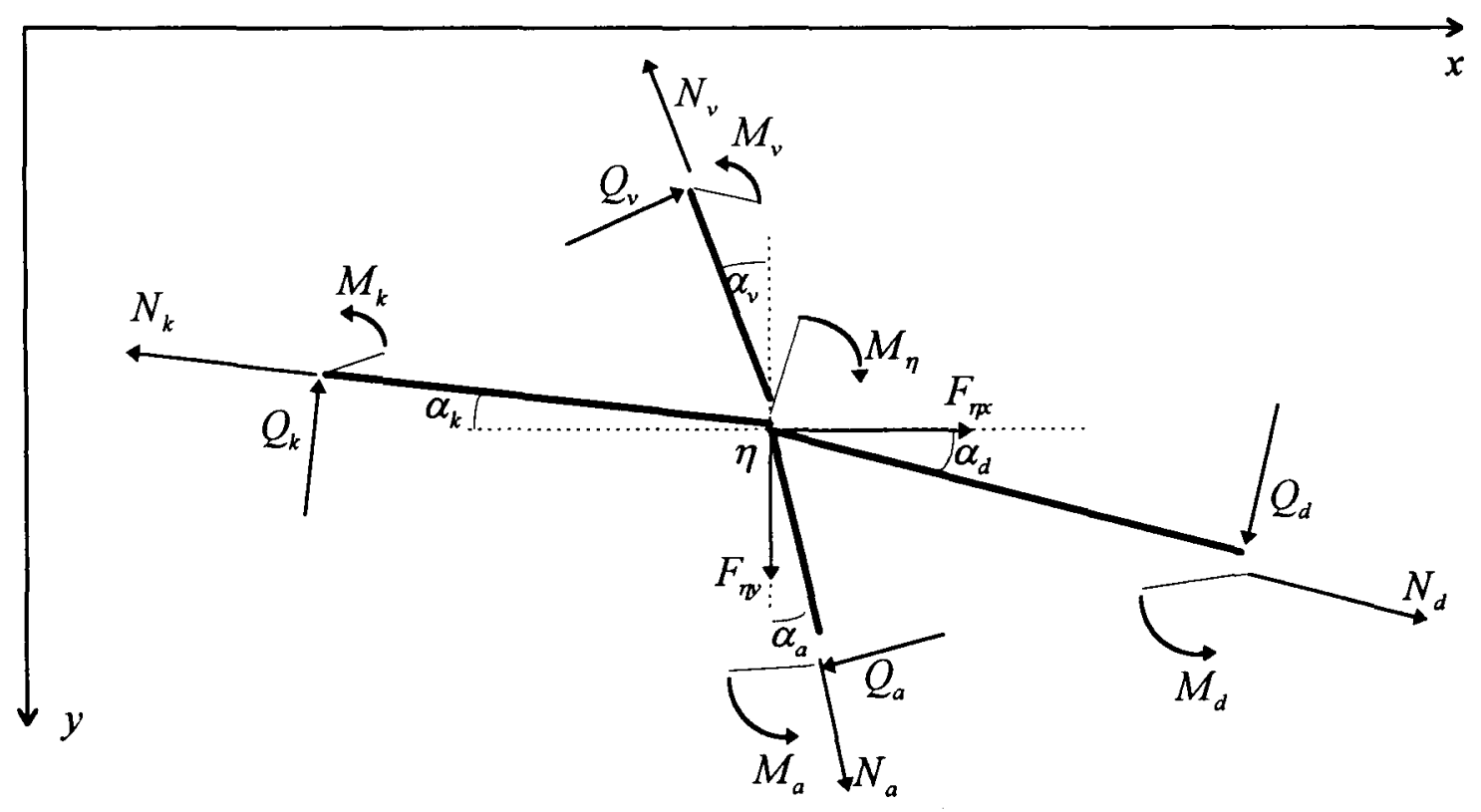

Fig 1. Joint due to deformed state

To determine geometrical dimensions consider the Fig 2. In global coordinate system, it shows the undeformed bar with coordinates $x_{p_{0}}, y_{p_{0}}, x_{g_{0}}, y_{g_{0}}$.

After deformation the coordinates obtained the positive increments $u_{p x}, u_{p y}, u_{g x}, u_{g y}$. Then the length of the bar is

$$
l=\sqrt{\left(l_{0 x}+u_{g x}-u_{p x}\right)^{2}+\left(l_{0 y}+u_{g y}-u_{p y}\right)^{2}},
$$

where

$$
\begin{gathered}
l_{0 x}=x_{g_{0}}-x_{p_{0}}, l_{0 y}=y_{g_{0}}-y_{p_{0}}, \\
\cos \alpha=\left(l_{0 x}+u_{g x}-u_{p x}\right) / l, \\
\sin \alpha=\left(l_{0 y}+u_{g y}-u_{p y}\right) / l .
\end{gathered}
$$

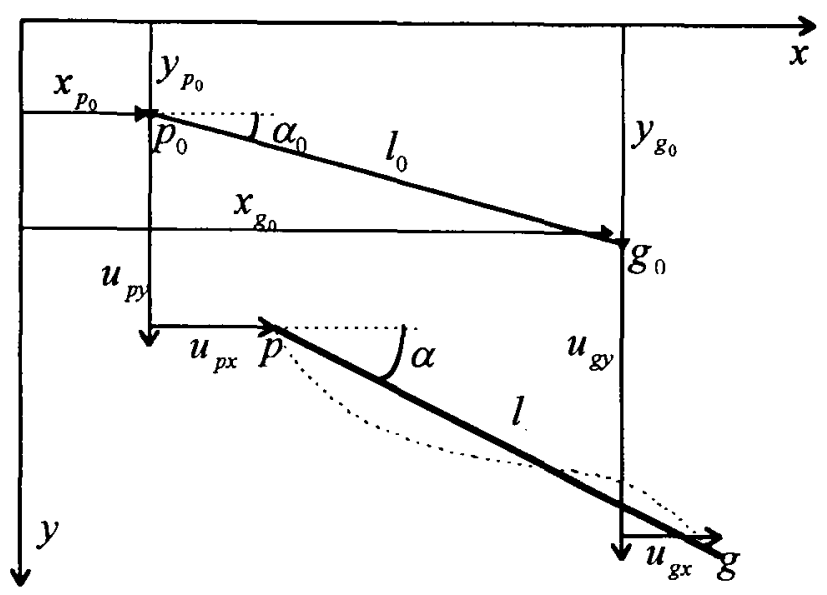

Fig 2. Deformed bar
Analysing equilibrium of deformed bar the shearing forces $Q_{p}=Q_{g}=-\left(M_{p}+M_{g}\right) / l$.

For the junction in Fig 1 equilibrium equations in matrix form read:

$$
\left[A_{\eta}(u)\right] \mathbf{S}_{\eta}=\mathbf{F}_{\eta}
$$

Here

$$
\begin{gathered}
\mathbf{S}_{\eta}=\left(M_{d p}, M_{d g}, M_{k p}, M_{k g}, M_{a p}, M_{a g},\right. \\
\left.M_{v p}, M_{v g}, N_{d}, N_{k}, N_{a}, N_{v}\right)^{T}, \\
{\left[A_{\eta}(u)\right]^{T}=\left[\begin{array}{ccc}
1 & -\sin \alpha_{d} / l_{d} & \cos \alpha_{d} / l_{d} \\
0 & -\sin \alpha_{d} / l_{d} & \cos \alpha_{d} / l_{d} \\
1 & \sin \alpha_{k} / l_{k} & -\cos \alpha_{k} / l_{k} \\
0 & \sin \alpha_{k} / l_{k} & -\cos \alpha_{k} / l_{k} \\
1 & -\cos \alpha_{a} / l_{a} & \sin \alpha_{a} / l_{a} \\
0 & -\cos \alpha_{a} / l_{a} & \sin \alpha_{a} / l_{a} \\
1 & \cos \alpha_{v} / l_{v} & -\sin \alpha_{v} / l_{v} \\
0 & \cos \alpha_{v} / l_{v} & -\sin \alpha_{v} / l_{v} \\
0 & -\cos \alpha_{d} & -\sin \alpha_{d} \\
0 & \cos \alpha_{k} & \sin \alpha_{k} \\
0 & -\sin \alpha_{a} & -\cos \alpha_{a} \\
0 & \sin \alpha_{v} & \cos \alpha_{v}
\end{array}\right]}
\end{gathered}
$$


This matrix is convienent to apply when formulating the global equilibrium matrix $[A(u)]$.

Now we discuss the question of formulation of the geometric equations of the bar. We consider moderately large deflections, of the order of the cross-section height magnitude. Then approximate relationship, usually applied to strain of any point in distance $y$ from neutral layer, can be realized by:

$$
\varepsilon_{x}=\frac{\partial u_{x}}{\partial x}+\frac{1}{2}\left(\frac{\partial u_{x}}{\partial x}\right)^{2}+\frac{1}{2}\left(\frac{\partial u_{y}}{\partial y}\right)^{2}-y \frac{\partial^{2} u_{y}}{\partial y^{2}}
$$

Thus, for nonlinear case the total strain consists of the membrane strain $\varepsilon_{x}^{0}=\partial u_{x} / \partial x+0,5\left(\partial u_{x} / \partial x\right)^{2}+$ $+0,5\left(\partial u_{x} / \partial\right)^{2}$ and the flexural strain $\varepsilon_{x}^{\prime}=-y\left(\partial^{2} u_{y} / \partial x^{2}\right)$

The first items in relationships $\varepsilon_{x}^{0}$ and $\varepsilon_{x}^{\prime}$ belong to linear theory. The remaining items in relationship $\varepsilon_{x}^{0}$ are the additional strains from nonlinear theory introduced to the theory of bar structures. They describe the tension not related to bending. For the bar in Fig 2 expressing the first derivatives in finite differences we have:

$$
\begin{aligned}
\varepsilon_{x}^{0} & =\frac{\Delta l}{l_{0}}=\frac{\left(u_{g x}-u_{p x}\right) \cos \alpha_{0}+\left(u_{g y}-u_{p y}\right) \sin \alpha_{0}}{2 l_{0} / 2}+ \\
& +\frac{1}{2}\left(\frac{\left(u_{g x}-u_{p x}\right) \cos \alpha_{0}+\left(u_{g y}-u_{p y}\right) \sin \alpha_{0}}{2 l_{0} / 2}\right)^{2}+ \\
& +\frac{1}{2}\left(\frac{\left(u_{g y}-u_{p y}\right) \cos \alpha_{0}+\left(u_{p x}-u_{g x}\right) \sin \alpha_{0}}{2 l_{0} / 2}\right)^{2}
\end{aligned}
$$

For general analysis, it is convienent to write this equation in reduced form. First, introduce a line matrix

$$
\left[A_{s 1}\right]=\left[\begin{array}{llll}
\cos \alpha_{0} & \sin \alpha_{0} & -\cos \alpha_{0} & \sin \alpha_{0}
\end{array}\right]
$$

and a vector

$$
\mathbf{u}_{s}=\left(u_{g x}, u_{g y}, u_{p x}, u_{p y}\right)^{T} .
$$

Secondly, introduce a quadratic matrix evaluating the nonlinear component of strain:

$$
\left[A_{s 2}\right]=\left[\begin{array}{rrrr}
\frac{1}{2 l_{0}} & 0 & -\frac{1}{2 l_{0}} & 0 \\
0 & \frac{1}{2 l_{0}} & 0 & -\frac{1}{2 l_{0}} \\
-\frac{1}{2 l_{0}} & 0 & \frac{1}{2 l_{0}} & 0 \\
0 & -\frac{1}{2 l_{0}} & 0 & \frac{1}{2 l_{0}}
\end{array}\right] \text {. }
$$

On the basis of above-mentioned, it is clear that elongation of neutral bar axis is longitudinal strain

$$
\Delta l=\varepsilon_{x}^{0} \cdot l=\left[A_{s 1}\right] \mathbf{u}_{s}+\mathbf{u}_{s}^{T}\left[A_{s 2}\right] \mathbf{u}_{s} .
$$

Now for the whole discrete model of the structure geometric equations read:

$$
\left[A\left(u_{0}\right)\right]^{T} \mathbf{u}+\left[A_{1}(u)\right]^{T} \mathbf{u}-\mathbf{q}=\mathbf{0} .
$$

Here matrix $\left[A\left(u_{0}\right)\right]^{T}$ is the transpose matrix of the equilibrium equation matrix $[A(u)]$, formed for undeformed state. Matrix $\left[A_{1}(u)\right]^{T}$ consists of multiplication products $\mathbf{u}_{s}^{T}\left[A_{s 2}\right]$ for every bar.

Adding the Hook's law $\mathbf{q}=[D] \mathbf{S}$, where $[D]$ symmetric $(n \times n)$-order flexibility matrix, to static and geometric equations, one obtains the equation system to solve geometrically nonlinear problems.

Thus, the mathematical model of the problem reads:

$$
\begin{gathered}
{[A(u)] \mathbf{S}=\mathbf{F},} \\
{\left[A\left(u_{0}\right)\right]^{T} \mathbf{u}+\left[A_{1}(u)\right]^{T} \mathbf{u}-\mathbf{q}=\mathbf{0},} \\
\mathbf{q}=[D] \mathbf{S} .
\end{gathered}
$$

By solving the (5) according to $u$, the system of equations to solve the problem in displacements reads:

$$
[A(u)]\left[K\left[A\left(u_{0}\right)\right]^{T} \mathbf{u}+[A(u)]\left[K \backslash\left[A_{1}(u)\right]^{T} \mathbf{u}=\mathbf{F}\right.\right.
$$

It is easy to find that the obtained system of nonlinear equations is cubic according displacements. This is the result of geometrically nonlinear behaviour of the structure. The two algorithms to solve the mathematical model (5) is to be presented.

\section{Complementary load method}

A deformation process trajectory in complementary load algorithm is considered by steps. The step 
of load parameter $\Delta F$ is introduced. Increasing the load by magnitude $\Delta \mathbf{F}_{v}$, the increments of forces $\Delta \mathbf{S}_{v}$ that of displacements $\Delta \mathbf{u}_{v}$ at the end of $v$-th step of load increment $\mathbf{F}_{v}=\sum \Delta \mathbf{F}_{v}$ are obtained. The stress state of the discrete model at the end $v$-th deformation step is described by $n$-dimension vector

$$
\mathbf{S}_{v}=\mathbf{S}_{\Sigma}+\Delta \mathbf{S}_{v}
$$

Here $S_{\Sigma}=\sum \Delta S_{v-1}$ - is the vector of total forces at the beginning of $v$-th step (usually for beginning of the loading process $S_{\Sigma}=0$ ).

Equilibrium equations at the end of $v$-th step read:

$$
\left[A\left(u_{\Sigma}\right)\right] \mathbf{S}_{v}=\mathbf{F}_{v}
$$

At the end of $v$-th loading step the matrix $\left[A\left(u_{\Sigma}\right)\right]$ is formed applying the displacements obtained as a sum product of previous $v$-1 steps (for beginning of the loading process $\mathbf{u}_{\Sigma}=0$ ).

As the discrete model of the structure at the end of $v$-th deformation step is in equilibrium, applying the principle of virtual displacements, the total work of all forces in virtual displacements must be equal to zero :

$$
\mathbf{F}_{v} \Delta \mathbf{u}_{v}-\mathbf{S}_{v}^{T} \Delta \mathbf{q}_{v}=0
$$

or

$$
\left[A\left(u_{\Sigma}\right)\right] \mathbf{S}_{v} \Delta \mathbf{u}_{v}-\mathbf{S}_{v}^{T}\left[A_{2}(u)\right] \Delta \mathbf{u}_{v}=\mathbf{0}
$$

From here it is easy to find that the matrices of static and geometric equations are dual, ie

$$
\left[A_{2}(u)\right]=\left[A\left(u_{\Sigma}\right)\right]^{T} \text {. }
$$

Note that the Hook's law at the $v$-th step is valid for stress and strain increments. Thus, the mathematical model of geometrically nonlinear problem in complementary load method reads:

$$
\begin{gathered}
{\left[A\left(u_{\Sigma}\right)\right] \mathbf{S}_{v}=\mathbf{F}_{v},} \\
{\left[A\left(u_{\Sigma}\right)\right]^{T} \Delta \mathbf{u}_{v}=\Delta \mathbf{q}_{v}} \\
\Delta \mathbf{q}_{v}=[D] \Delta \mathbf{S}_{v}
\end{gathered}
$$

The order of calculations usually is as follows. By eliminating the strain increments $\Delta \mathbf{q}_{v}$ from the system (7), one obtains:

$$
\left[A\left(u_{\Sigma}\right)\right] \Delta \mathbf{S}_{v}=\mathbf{F}_{v}-\left[A\left(u_{\Sigma}\right)\right] \mathbf{S}_{\Sigma}
$$

$$
\left[A\left(u_{\Sigma}\right)\right]^{T} \Delta \mathbf{u}_{v}=[D] \Delta \mathbf{S}_{v}
$$

By solving the second equation according to $\Delta \mathbf{S}_{v}$ and applying in the first equation, we have:

$$
\left[A\left(u_{\Sigma}\right)\right][D]^{-1}\left[A\left(u_{\Sigma}\right)\right]^{T} \Delta u_{v}=\mathbf{F}_{v}-\left[A\left(u_{\Sigma}\right)\right] \mathbf{S}_{\Sigma}
$$

From here

$$
\begin{gathered}
\Delta \mathbf{u}_{v}=\left\{\left[A\left(u_{\Sigma}\right)\right][D]^{-1}\left[A\left(u_{\Sigma}\right)^{T}\right]\right\}^{-1} \mathbf{F}_{\nu}- \\
-\left\{\left[A\left(u_{\Sigma}\right)\right][D]^{-1}\left[A\left(u_{\Sigma}\right)^{T}\right]\right\}^{-1}\left[A\left(u_{\Sigma}\right)\right] \mathbf{S}_{\Sigma}, \\
\Delta \mathbf{S}_{v}=[D]^{-1}\left[A\left(u_{\Sigma}\right)\right]^{T} \Delta \mathbf{u}_{v} .
\end{gathered}
$$

One finds that design process is realised by solution of linear equations, determining the changes of all geometric parameters. Every new step of load is applied to the structure, deformed by loads of previous steps.

\section{The Newton-Raphson method}

Short about solution method of nonlinear problem (5) by means of Newton-Raphson method.

Let vector $\mathbf{u}_{v}$ be the $v$-th iteration vector of displacements . Substituting this vector for the second and third equation of the system (5) the vector of forces is

$$
\mathbf{S}_{v}=[D]^{-1}\left[A\left(u_{0}\right)\right]^{T} \mathbf{u}_{v}+[D]^{-1}\left[A_{1}\left(u_{v}\right)\right] \mathbf{u}_{v} .
$$

Applying (10) in equations (5) the vector of inadequacy is obtained as the vector function of displacements:

$$
\Psi\left(u_{v}\right)=\left[A\left(u_{v}\right)\right] \mathbf{S}_{v}-\mathbf{F}
$$

Expressing the function $\psi\left(u_{\nu}\right)$ by the Taylor line around the point $u_{v}$ and taking into account the one item, one obtains

$$
\psi\left(u_{v}\right)+\left[d \psi\left(u_{v}\right) / d u\right] \Delta \mathbf{u}_{v}=\mathbf{0} .
$$

From here

$$
\Delta \mathbf{u}_{v}=-\left[d \psi\left(u_{v}\right) / d u\right]^{-1} \psi\left(u_{v}\right)
$$

Thus, the formula to determine the aproximate solution $\mathbf{u}^{*}$ for the step $(v+1)$ is obtained:

$$
\mathbf{u}_{v+1}=\mathbf{u}_{v}+\Delta \mathbf{u}_{v} .
$$

The recurrence formula (13) is the basis of the Newton-Raphson method to receive the roots $u^{*}$ of 
the equations (6). Applying them in the formula (10), the vector $\mathbf{S}^{*}$ is obtained.

To obtain the vector of increments $\Delta u_{v}$ the differential of the inadequacy function $\psi\left(u_{v}\right)$ must be calculated:

$$
d \psi\left(u_{v}\right)=d\left[A\left(u_{v}\right)\right] \mathbf{S}_{v}+\left[A\left(u_{v}\right)\right] d \mathbf{S}_{v}
$$

According to the second equation of the system (7a), one obtains $\left[A\left(u_{v}\right)\right]^{T} d \mathbf{u}_{v}=[D]^{-1} d \mathbf{S}_{v}$. From here

$$
d \mathbf{S}_{v}=[D]^{-1}\left[A\left(u_{v}\right)\right]^{T} d \mathbf{u}_{v} .
$$

An expression $d\left[A\left(u_{v}\right)\right] \mathbf{S}_{v}$ contains linear the displacement differentials $d \mathbf{u}_{v}$, therefore this expression can be expressed by:

$$
d\left[A\left(u_{v}\right)\right] \mathbf{S}_{v}=\left[K_{2}\left(S_{v}\right)\right] d \mathbf{u}_{v} .
$$

Substituting (15) and (16) by (14) one obtains :

$$
d \psi\left(u_{v}\right)=[K] \mathrm{d} \mathbf{u}_{v} .
$$

Here $[K]=\left\{\left[K_{1}\left(u_{v}\right)\right]+\left[K_{2}\left(S_{v}\right)\right]\right\}-(m \times m)$ is the dimension tangential stifness matrix; $\left[K_{1}\left(u_{v}\right)\right]$ - the usual linear stiffness matrix.

From relationship (17) the tangential stiffness matrix $[K]=\left[d \psi\left(u_{v}\right) / d u\right]$. Substituting it for (12) the displacement increments vector for the following step is:

$$
\Delta \mathbf{u}_{v}=-[K]^{-1} \psi\left(u_{v}\right) .
$$

In the case of nonsuccessfull vector $\mathbf{u}_{v}$, the iteration process converges slowly and in some cases

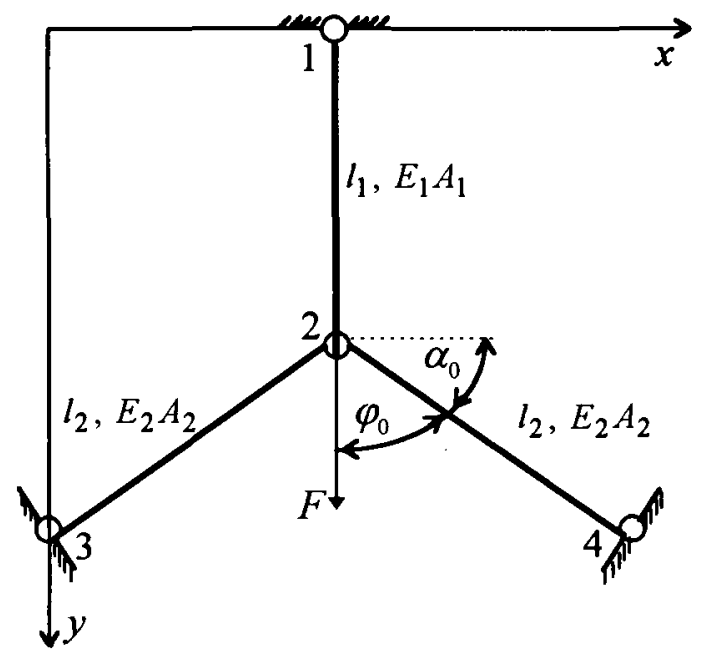

Fig 3. Three bar structure does not converge at all. Therefore the displacement vector $\mathbf{u}_{v}$ for the first step from the geometrically linear solution is proposed.

\section{Solution example}

Consider the SSF of the physically linear and geometrically nonlinear bar system in Fig 3 affected by vertical load $F$.

This problem clearly illustrates the influence of the nonlinear theory. In [8] for $\varphi_{0}=60^{\circ}$ and $l_{1}=l_{2}=l_{0}, E_{1} A_{1}=E_{2} A_{2}=E A$ the exact analytical solution of the problem is:

$$
\begin{aligned}
F=2 E A & \frac{\beta}{2} \xi+ \\
& +\left(\frac{1}{\sqrt{1-2 \xi \cos \varphi_{0}+\xi^{2}}}-1\right)\left(\cos \varphi_{0}-\xi\right) .
\end{aligned}
$$

For

$$
\beta=\frac{l_{2} E_{1} A_{1}}{l_{1} E_{2} A_{2}}=1, \xi=\frac{u_{2 y}}{l_{0}}=\frac{0,2 l_{0}}{l_{0}}=0.2 \mathrm{~m}, E A=1 \mathrm{kN}
$$

the geometrically nonlinear load solution is $F=$ $0,2546536 \mathrm{kN}$. By solving the problem by means of complementary load method (7), the exact displacement solution $u_{2 y}=0,2 l_{0}$ is obtained for the $\Delta F=F / 60$. For $\Delta F=F / 40$ deviation from exact solution is $0,3 \%$, for $\Delta F=F / 20-1,16 \%$, and for $\Delta F=F / 10-2,5 \%$. Applying the Newton-Raphson method (10)-(18) exact solution is reached in five iterations, when for first step the geometrically linear solution $u_{2 y}=0,1697691 l_{0}$ is applied. For considered problem $u_{2 x}=0, N_{2-3}=N_{2-4}=N_{2}, \Delta l_{2-3}=\Delta l_{2-4}=$ $=\Delta l_{2}$. Then the matrix of geometric equations is

$$
\left[A\left(u_{0}\right)\right]^{T}+\left[A_{1}(u)\right]^{T}=\left[\begin{array}{c}
1+u_{2 y} / 2 l_{0} \\
-\sin \alpha_{0}+u_{2 y} / 2 l_{0}
\end{array}\right],
$$

and tangential stifness matrix

$$
\begin{gathered}
{[K]=\left\{\left[K_{1}\left(u_{v}\right)\right]+\left[K_{2}\left(S_{v}\right)\right]\right\} \text { changes to a scalar }} \\
\frac{E A}{l_{0}}\left(2 \sin ^{2} \alpha+1\right)+\frac{2 N_{2}}{l}\left(1-\sin ^{2} \alpha\right) .
\end{gathered}
$$

Analysis of results clearly illustrates the influence of geometrical nonlinearity on the magnitude of displacements: for the same load $F=0,2546536 \mathrm{kN}$. The diplacements of geometrically linear system are by $15,1 \%$ less than calculating them for geometrically nonlinear system. 


\section{Conclusions}

1. The SSF of the structure can be determined by applying the mathematical model (5). It makes up a system of nonlinear algebraic equations, which can be solved according to the displacements. Thus, the cubic equations system (6) is obtained.

2. Design process of the cubic eqs system when the complementary load method is applied, is realised by solution of linear equations. The equilibrium matrix is formed for every load step, taking into account the deformation history due to the previous load steps. Therefore, the geometric eqs matrix is transposed matrix of equilibrium eqs and the cubic eqs system (6) is transformed into linear eqs system.

3. Applying the Newton-Raphson method, the roots of the eqs (6) can be obtained, using the recurrence formula (13), in which the displacement vector from geometrical linear design is proposed for the first iteration.

4. The solved numerical examples have shown the efficiency of the proposed methods while solving the geometrically nonlinear elastic-plastic structure optimization and analysis problem.

\section{References}

1. O.C.Zienkiewicz, R.L.Taylor. The Finite Element Method. Solid and Fluid Mechanics, Dynamics and Nonlinearities. Vol. 2. London: McGraw-Hill, 1991. $807 \mathrm{p}$.

2. M.A.Crisfield. Non-linear Finite Element Analysis of Solids and Structures, vol.1, Essentials. Chichester: John Wiley\&Sons, 1991. 350 p.

3. R.Kačianauskas. Computer Methods in Multilevel Modelling of Beams and Shells. Vilnius: Technika, 1995. 395 p.

4. K-J.Bathe. Finite Element Procedures in Engineering Analysis. New-Jersey: Prentice-Hall, 1982. 406 p.

5. E.Reissner. Variational Principles in Elasticity, in: Finite Element Handbook, H.Kardestuncer, D.H.Norrie (ed.). New-York, McGraw-Hill, 1987, p. 2.3-2.19.

6. T.Belytschko, M.Velebit. Finite Element Method for Elastic Plastic Plates // J. Eng. Mech. Div. Proc. Amer. Civ.Eng., 98, №1, 1972, p. 227-242.

7. С.Каланта. Равновестные конечные элементы в расчетах упругих конструкций // Statyba, №1(1), Вильнюс: Техника, 1995, с. 25-47.

8. П.А.Лукаш. Основы нелинейной строительной механики. Москва: Стойиздат, 1978. 204 с.

\section{APIE GEOMETRIŠKAI NETIESINIŲ STRYPINIU SISTEMŲ SKAIČIAVIMĄ}

\section{R. Karkauskas}

San tra u k a

Nagrinèjame itempčiu ir deformaciju būsenos (IDB) nustatymą plokščiose strypinėse sistemose, kai poslinkiai dideli, o deformacijos mažos. Siuo atveju pusiausvyros lygtys sudaromos nepaisant strypų deformacijų.

Geometriškai netiesinių tampriy̨ sistemy İDB galima skaičiuoti pagal sudarytą (5) matematini modelí, jungiantị $i$ netiesiniu lygčiu sistemą visus ieškomuosius dydžius (irąžas, poslinkius ir deformacijas). Jos supaprastintas variantas yra kubiniy lygčiu (6) sistema, kurioje pagrindiniai nežinomieji yra vien poslinkiai u. Tačiau ir šios sistemos sprendimas komplikuotas.

Siūlomi du IDB nustatymo keliai. Pirmasis - papildomos apkrovos metodas. Taikant ši metodą skaičiuojama etapais. Pasirenkamas apkrovos žingsnis $\Delta F$. Nuosekliai didinant apkrovą šiuo žingsniu randami poslinkių ir ịrąžu prieaugiai $\Delta \mathbf{u}_{v}$ ir $\Delta \mathbf{S}_{v}$. Cia kiekviename apkrovimo etape pusiausvyros lygčių matrica $\left[A\left(u_{\Sigma}\right)\right]$ sudaroma atsižvelgiant $i$ ankstesniy apkrovimo etapy konstrukcijos deformavimo istoriją, o geometrinių lygčių matrica yra transponuota $\left[A\left(u_{\Sigma}\right)\right]^{T}$. Dèl to kubinių lygčių sistema (6) tampa tiesiniu lygčių sistema, kurios sprendinys yra poslinkiy prieaugiu vektorius $\Delta \mathbf{u}_{v}$, randamas pagal (8) išraišką. Po to pagal (9) išraišką randamas $\Delta \mathbf{S}_{v}$.

Antrasis būdas IDB skaičiuoti yra pagrịstas NiutonoRafsono metodu. Čia naudojant rekurenciają formulę (13), kurioje poslinkių prieaugiai skaičiuojami pagal (18) formulę, randamos kubinès lygties (6) saknys. NiutonoRafsono metodas pradinei iteracijai poslinkių vektorių $\mathbf{u}_{v}$ siūlo imti iš geometriškai tiesinio skaičiavimo.

Abieju metody taikymas iliustruojamas pavyzdžiais. Atlikti skaitiniai eksperimentai atskleidé siūlomy metody efektyvumą ir jų galimybę taikyti geometriškai netiesinių tampriu-plastiniu sistemy analizès ir optimizavimo uždaviniams.

Romanas KARKAUSKAS. Doctor, Associate Professor. Department of Structural Mechanics. Vilnius Gediminas Technical University, 11 Sauletekio Ave, 2040 Vilnius, Lithuania. Dr degree in 1972 (structural mechanics). Research visits: Warsaw Politechnic Institute, Moscow Civil Engineering Institute, Kiev Civil Engineering Institute. Research interests: analysis and optimization of elastic-plastic structures, computational mechanics.

İteikta 19970915 